\title{
Safety of Bifidobacterium longum BB.536 Fermented Sudanese Rice Types Denoted Locally as Crown, Narica and Pabenjeda Beverages Assessed on Albino Rats
}

\author{
Barka Mohammed Kabeir $^{{ }^{*}}$ and Maha Abdalla Mohamed Ibrahim ${ }^{2}$ \\ ${ }^{1}$ Department of Food Science and Technology, College of Agricultural Studies, Sudan \\ University of Science and Technology, Khartoum, SUDAN \\ ${ }^{2}$ Sudanese Standardization and Metrology Organization, Cancel of Ministers, SUDAN \\ *Corresponding author
}

\section{A B S T R A C T}

\begin{tabular}{|l|}
\hline Ke y w o r d s \\
Sudanese, Rice, \\
Beverage, \\
Bifidobacterium, \\
Safety, Rats
\end{tabular}

Safety of three different Sudanese rice types denoted locally (Crown, Narica and Pabenjeda) beverages, fermented with Bifidobacterium longum BB.536 after supplementation with whey and hashab gum Arabic was assessed using albino rats. $10 \mathrm{~g}$ of rice flour (w/v) was cooked at $60{ }^{\circ} \mathrm{C}$ using a hot plate for $7 \mathrm{~min}$; after cooling $1 \mathrm{~g}$ of fetarita sorghum malt was added followed by addition of $10 \mathrm{ml}$ whey and $1 \mathrm{~g}$ hashab gum. The mix was sterilized at $121^{\circ} \mathrm{C}$ for 15 min., cooled to $37^{\circ} \mathrm{C} .3 \%$ active B. longum BB.536 starter culture was added and incubated at $37^{\circ} \mathrm{C}$ for $36 \mathrm{hrs}$ (maximum growth). Four weeks old albino rats with an average initial weight of $(110 \mathrm{~g} \pm 10)$ were acclimatization for fifteen days and assigned randomly to four groups $(\mathrm{n}=6)$. Control group orally fed daily $3 \mathrm{ml}$ distilled water. Other three groups were daily orally fed $3.0 \mathrm{ml}$ of fermented Crown rice beverage supplemented with whey and hashab gum, fermented Narica rice beverage supplemented with whey and hashab gum, fermented Pabenjeda rice beverage supplemented with whey and hashab gum. Different analyses were carried out including general health, haematology and blood biochemistry analysis. Feeding experimental rats with the fermented rice beverages supplemented with whey and hashab gum did not show any abnormal changes in behaviour, activity and no signs of illness, but it showed a significant $(\mathrm{p}<0.05)$ difference in weight gain when compared treated rats with the control rats during the feeding period. Blood analysis results for treated rats showed positive health signs in CBC, RBC, HGB, liver enzymes ALP, ALT and AST as it were within the normal range for rat blood. Nevertheless there were a significant $(\mathrm{p}<0.05)$ decrease in the level of cholesterol, triglyceride and blood glucose as signs of health benefits. Therefore, all probiotic strain BB.536 fermented rice beverages supplemented with whey and hashab gums were safe and exerted some beneficial effects to fed rats.

\section{Introduction}

Rice (Oryza sativa L.) is one of the most important cereal crops and is the staple food of over half the world's population. It is also one of the largest consumed agricultural crops in the world, only next to maize. Rice is consumed after de-hulling process and 
whitening or removal of bran layer and embryo (Blandino et al., 2003). Whey and whey derived products besides being nutritional ingredients in various foods can also be used as functional ingredients supplying flavour, texture, colour and aeration properties in a variety of foods. Whey contained most of the milk sugar about $20 \%$ of milk protein, water soluble vitamins and minerals (Shreyansh et al., 2013; Marshall and harper, 1988). On the other hand, prebiotic is mainly indigestible food item that usefully affect the host by selectively stimulating the growth and activity of one or numbers of beneficial bacteria in the large intestine, and thus improves the host health (Gibson and Roberfroid, 1995). In fact, the non-digestible prebiotics such as inulin, fructooligosaccharide (FOS), sorbitol and arabinan selectively stimulated the growth and /or activity of indigenous probiotics bifidobacteria and Lactobacillus in the intestinal tract (Gibson and Roberfroid, 1995; De-Vaux et al., 2002, Tamime et al., 2006).

Gum arabic or acacia gum is the exudate from the Acacia senegal and Acacia seyal trees, belonging to Leguminosae family. It is a complex, branched hetero-polysaccharide soluble in water, neutral or slightly acidic salt of a complex polysaccharide containing calcium, magnesium and potassium salt (Shirwaikar et al., 2008). Moreover, it is acomplex edible mixture of saccharides and glycoprotein composed of 1, 3-linked $\beta$-dgalactopyranosyl units. L-arabinose, Lrhamnose, anglucuronic which gives it most useful property (Abdul-Hadi et al., 2010).

Probiotics defined as microbial dietary adjuvant that beneficially affects the host physiology by modulating mucosal and systemic immunity, as well as improving nutritional and microbial balance in the intestinal tract. Mainly specific strains of lactobacillus, Bifidobacterium, enterococci and yeast are today used commercially as probiotics in foods (Naidu et al., 1999; Holzapfel et al., 1995; Saxelin et al., 1995). The functional foods are the food that can positively impact the health as it contains health promoting and biologically active components in adequate amounts (Prado et al., 2008; Siro et al., (2008). These foods improves the general and physical conditions of the human organism and/or decrease the risk of occurrence of disease, it either be dairy based or cereal based. It is prepared by inclusion of other ingredients such as probiotics and prebiotics to levels that enable the consumer to derive optimal health benefits. The presence of probiotics and prebiotics in the same product is termed as synbiotic (Schrezenmeir and de Vrese, 2001). The approach has been reported to enhance the efficiency through supporting viability and enhancing enzymatic activity of probiotics (Collins and Gibson, 1999). Synbiotic products enhance the growth and survival of probiotic bacteria in fermented dairy products (Desai et al., 2004). Bifidobacterium longum is the most common species of bifidobacteria being found in both infant and adult (Ventura et al., 2007).Many scientific studies showed the benefits offered by Bifidobacterium longum BB536 (Kojima et al., 1996; Namba et al., 2003). Thus there is considerable interest in incorporating these heaths promoting bifidobacterium into food. In this study Bifidobacterium longum BB536 fermented products from local rice types was formulated using whey and hashab gum Arabic to assess their safety on orally fed albino rats.

\section{Materials and Methods}

\section{Rice varieties}

Long grain rice locally denoted (Crown) planted in Sudan was collected from supermarket in Khartoum State. Papenjeda 
rice is a wild rice grown in white Nile State was collected from the local market in Kosti Town. Narica rice planted in Algazira scheme was obtained from the Rice Department, Ministry of Agriculture, (Khartoum - Sudan). Care was taken to ensure that good quality of rice grains was selected.

\section{Gum arabic}

Hashab was obtained from north Kordofan State (from batches prepared for export).

\section{Milk}

Fresh cow milk was obtained from Department of Animal Production, Collage of Agriculture Studies, Sudan University of Science and Technology (SUST).

\section{Sorghum malt}

Fitareta sorghum grain was obtained from Agricultural Research Corporation (ARC), Wad Medani, Sudan. Fitareta sorghum grains were malted following Kabeir et al., (2015) methods.

\section{Bifidobacterium longum BB536}

Bifidobacterium longum BB536 strain was obtained from the stock culture of Microbiology Laboratory (Department of Food Science and Technology, College of Agricultural Studies, University of Sudan Science and Technology, Sudan). The strain was maintained at $-20{ }^{\circ} \mathrm{C}$ in $20 \%$ glycerol solution.

Fermentation of the three different rice varieties supplemented with sorghum malt, whey and gum arabic

$10 \%$ of different types of rice flour (w/v) were prepared in a separate volumetric flask. The mixture was cooked in hot plate at $60{ }^{\circ} \mathrm{C}$ for 7 minutes. After cooling $1 \%$ feterita sorghum malt was added for liquification. Then $10 \% \mathrm{ml}$ of whey (V/V) and $1 \%$ hashab gum arabic (w/v) were supplemented.

The final mixture was autoclaved at $121{ }^{\circ} \mathrm{C}$ for 15 minutes, cooled to $37^{\circ} \mathrm{C}, 3 \%$ active culture of Bfidobacterium longum BB536 was added followed by incubation at $37^{\circ} \mathrm{Cfor} 48$ hours.

\section{Albino rats}

Four weeks old albino rats with an average initial weight of $110 \pm 10 \mathrm{~g}$ were purchased from College of Pharmacy, Ahfad University for Women (Khartoum, Sudan). A 12 h light dark cycle and a controlled atmosphere (25 $\pm 2^{\circ} \mathrm{C}$ ) were maintained throughout the study. After fifteen days acclimatization period under experimental condition, a total of 24 rats were weighed and assigned randomly to four feeding treatment $(n=6)$ for 30 days.

During the trial, all rat groups had free access to water and standard normal feed for 6 weeks. The four rats group were placed in a plastic cages protected with stainless, the bed covers in cages was changed twice a week. The experiment protocol was abided to the animal Ethics of Sudan University of Science and Technology and adhered to guiding principle in the care and use of animals in experiments.

\section{Rats experimental groups}

Control group orally fed daily $3 \mathrm{ml}$ distilled water. Other three groups were daily orally fed $3.0 \mathrm{ml}$ of fermented Crown rice beverage supplemented with whey and hashab gum, fermented Narica rice beverage supplemented with whey and hashab gum, fermented Pabenjeda rice beverage supplemented with whey and hashab gum. 


\section{Evaluation of general health of rats}

The general health of the fed rats was observed and recorded based on feed intake, water consumption, weight gain, eyes character, difference in hair, abnormal behavioral characteristics, and rat activity.

\section{Blood samples collection}

At the end of the experiment, the rats were anesthetized with diethyl ether, and the blood is obtained from orbital sinus by using heparinized capillary tubes. Blood samples from three rats of each treatment group were immediately placed in sterilized tubes containing $40 \mathrm{ml}$ EDTA and kept at $4^{\circ} \mathrm{C}$ for hematology analysis. The blood samples from the other three rats of each treatment group were collected in sterile tubes and centrifuged at $15000 \mathrm{rpm}$ for 20 minute to obtain the serum for biochemical analysis.

\section{Blood hematological analysis}

Blood samples were analyzed for complete blood profile: red blood cell (RBC), white blood cell (WBC), platelet (PL), hemoglobin concentration (HGB), and leukocyte differential count (NEU, LYM, etc.), platelet count (PLT), hematocrit (HCT), and red blood cell indices: mean corpuscular volume (MCV), mean corpuscular hemoglobin $(\mathrm{MCH})$, mean corpuscular hemoglobin concentration (MCHC). The measurements were performed by Heamatology Analyzer (sys mex kx-21N-USA).

\section{Blood biochemistry analysis}

Blood serum were subjected to evaluation of alanine amino transferase (ALT), aspartate amino transferase (AST), lactate dehydrogenase (LDH), and alkaline phosphatase (ALP) activities, total protein, albumin, globulin, urea, creatinine $\mathrm{Na}$, ca, $\mathrm{k}$,
P, and blood glucose levels. All parameters were measured using Blood Clinical Analyzer (COBAS INTEGRA 400PLUS- Switzerland).

\section{Statistical analysis}

One- way ANOVA was performed to examine significant differences between normally distributed data. Probability level of less than 0.05 was considered significant $(\mathrm{p}<0.05)$. All data were analysed using vision 17 MINITAB statistical software for windows (2006).

\section{Results and Discussion}

Behavioural characteristics of rats group orally fed different fermented rice beverages supplemented with whey and hashab gum

All rat survived during the study period. In addition, all rats did not showed any symptoms of illness, having normal eyes shape, normal alertness, ease response for catching, having normal sleeping (Table 1). However, rats groups received different strain BB 536 fermented rice supplemented with whey and hashab gum showed white smooth hair and having normal sensitivity to temperature as compared with the control group which were sensitive to temperature often having bath in water dish and their hair was not smooth (Table 1).

Feed consumption and water intake of rats groups orally fed different fermented rice beverages supplemented with whey and hashab gum

Tables 2 and 3 showed the feed consumption and water intake of rat groups orally fed different fermented rice beverages. There were significant $(\mathrm{p}<0.05)$ difference between different groups of rats in feed consumption and water intake. 
Crown rice fermented beverage fed group showed the lowest total feed consumption moreover, Narica rice fermented beverage fed group showed the lowest total water intake. While the control group recorded the highest total feed consumption and water intake (Tables 2 and 3).

Weight of rats orally fed different fermented rice beverages supplemented with whey and hashab gum

All groups of rats showed normal growth pattern with differences in actual weight gain throughout the treatment period of 6 weeks (Table 4). Rats group fed fermented Pabenjeda rice beverage gained the highest weight of $27.40 \mathrm{~g}$, whereas the control group recorded the lowest weight of 17.1g (Table 4).

Blood haematology of rats orally fed different fermented rice beverages supplemented with whey and hashab gum

The result of blood haematology of rats fed different strain BB536 fermented rice beverages supplemented with why and hashab gun was presented in Table 5. There was no significant $(\mathrm{P}<0.05)$ differences in all haematological parameter between different groups of rats including the control; except in MPV for rat group fed fermented Narica rice and RWD for rat group fed fermented for rat group fed fermented Narica rice.

Table.1 Behaviour of rats group orally fed different fermented rice beverages supplemented with whey and hashab gum

\begin{tabular}{|c|c|c|c|c|}
\hline \multirow[t]{2}{*}{ Behaviour Characteristic } & \multicolumn{4}{|c|}{ Rat groups orally fed different fermented rice supplemented with whey and gum } \\
\hline & Control & Crown & Narica & Pabenjeda \\
\hline Survival & $100 \%$ & $100 \%$ & $100 \%$ & $100 \%$ \\
\hline Illness symptoms & No & No & No & No \\
\hline Activity & Active & Very active & Very active & Very active \\
\hline Eyes shape & Normal shape & Normal shape & Normal shape & Normal shape \\
\hline Hair & White hair & White smooth hair & White smooth hair & White smooth hair \\
\hline $\begin{array}{l}\text { Behaviour: } \\
\text { * Alertness } \\
\text { * Response to catching } \\
\text { * Sleeping } \\
\text { * Temperature sensitivity }\end{array}$ & $\begin{array}{l}\text { - Normal } \\
\text { - Easy } \\
\text { - Normal } \\
\text { - Very sensitive often having } \\
\text { bath in water dish }\end{array}$ & $\begin{array}{l}\text { - Normal } \\
\text { - Easy } \\
\text { - Normal } \\
\text { - Normal }\end{array}$ & $\begin{array}{l}\text { - Normal } \\
\text { - Easy } \\
\text { - Normal } \\
\text { - Normal }\end{array}$ & $\begin{array}{l}\text { - Normal } \\
\text { - Easy } \\
\text { - Normal } \\
\text { - Normal }\end{array}$ \\
\hline
\end{tabular}

\section{Control Daily $3.0 \mathrm{ml}$ orally distilled water}

Crown Daily $3.0 \mathrm{ml}$ orally fed fermented Crown rice beverage

Narica Daily $3.0 \mathrm{ml}$ orally fed fermented Narica rice beverage

Pabenjeda Daily $3.0 \mathrm{ml}$ orally fed fermented Pabenjeda rice beverage

Table.2 Feed consumption (g) of rats groups orally fed different fermented rice beverages supplemented with whey and hashab gum

\begin{tabular}{|c|c|c|c|c|c|}
\hline $\begin{array}{c}\text { Groups of Rats fed } \\
\text { fermented rice }\end{array}$ & Week 1 & Week 2 & Week 3 & Week 4 \\
\hline Crown & $100 \pm 0.00_{d}$ & $107 \pm 0.02_{c}$ & $115.7 \pm 36.9{ }_{b}$ & $130.0 \pm 6.32_{\mathrm{a}}$ \\
\hline Narica & $121.43 \pm 10.69_{\mathrm{c}}$ & $106.43 \pm 6.27_{\mathrm{d}}$ & $120.57 \pm 6.90_{\mathrm{b}}$ & $131.67 \pm 4.08_{\mathrm{a}}$ & 482.72 \\
\hline $\begin{array}{c}\text { Pabenjeda } \\
\text { Control }\end{array}$ & $112.86 \pm 17.04_{\mathrm{d}}$ & $135.71 \pm 15.12_{\mathrm{b}}$ & $160.00 \pm 11.55 \mathrm{~b}_{\mathrm{a}}$ & $123.33 \pm 8.16_{\mathrm{c}}$ \\
\hline $113.23 \pm 12.15_{\mathrm{d}}$ & $130.30 \pm 10.07_{\mathrm{c}}$ & $142.21 \pm 14.20_{\mathrm{b}}$ & $154.71 \pm 15.30_{\mathrm{a}}$ & 539.00 \\
\hline
\end{tabular}

Values are mean \pm SD of six rats

Values that bear different superscript letter in the same row in each specific week are significantly different at $\mathrm{p}<0.05$.

Control Daily $3.0 \mathrm{ml}$ orally distilled water

Crown Daily $3.0 \mathrm{ml}$ orally fed fermented Crown rice beverage

Narica Daily $3.0 \mathrm{ml}$ orally fed fermented Narica rice beverage

Pabenjeda Daily $3.0 \mathrm{ml}$ orally fed fermented Pabenjeda rice beverage 
Table.3 Water intake $(\mathrm{ml})$ of rats groups fed different fermented rice beverage supplemented with whey and hashab gum

\begin{tabular}{|c|c|c|c|c|c|}
\hline $\begin{array}{l}\text { Groups of Rats fed } \\
\text { fermented rice }\end{array}$ & Week 1 & Week 2 & Week 3 & Week 4 & $\begin{array}{l}\text { Total water } \\
\text { Consumption }\end{array}$ \\
\hline Crown & $134.29 \pm 12.72_{b}$ & $140.00 \pm 17.32$ & $134.29 \pm 15.12_{b}$ & $131.67 \pm 4.08_{c}$ & 540.25 \\
\hline Narica & $134.51 \pm 11.24_{b}$ & $142.86 \pm 14.96$ & $134.29 \pm 14.96_{b}$ & $130.56 \pm 5.08_{c}$ & 521.22 \\
\hline $\begin{array}{l}\text { Pabenjeda } \\
\text { Control }\end{array}$ & $\begin{array}{l}137.14 \pm 13.8_{\mathrm{c}} \\
139.5 \pm 11.20_{\mathrm{c}}\end{array}$ & $\begin{array}{l}142.86 \pm 12.54_{b} \\
143.32 \pm 11.12_{b}\end{array}$ & $\begin{array}{l}148.57 \pm 18.46 \mathrm{a} \\
148.81 \pm 14.20_{\mathrm{a}}\end{array}$ & $\begin{array}{l}123.33 \pm 8.16_{\mathrm{d}} \\
124.32 \pm 5.46_{\mathrm{d}}\end{array}$ & $\begin{array}{l}551.90 \\
555.95\end{array}$ \\
\hline
\end{tabular}

Values are mean \pm SD.

Values that bear different superscript letter in the same row in each specific week are significantly different at $\mathrm{p}<0.05$.

Control Daily $3.0 \mathrm{ml}$ orally distilled water

Crown Daily $3.0 \mathrm{ml}$ orally fed fermented Crown rice beverage

Narica Daily $3.0 \mathrm{ml}$ orally fed fermented Narica rice beverage

Pabenjeda Daily $3.0 \mathrm{ml}$ orally fed fermented Pabenjeda rice beverage

Table.4 Weight (g) of rats fed fermented rice beverages supplemented with whey and hashab gum

\begin{tabular}{|l|c|c|c|c|}
\hline \multirow{2}{*}{ Weight } & \multicolumn{4}{|c|}{ Rat groups orally fed different fermented rice supplemented with whey and gum } \\
\cline { 2 - 5 } & Crown & Narica & Pabenjeda & Control \\
\hline Initial & $108.57 \pm 17.45$ & $114.14 \pm 13.61$ & $120.43 \pm 21.19$ & $97.57 \pm 11.67$ \\
\hline Final & $133.50 \pm 22.50$ & $139.83 \pm 13.76$ & $147.83 \pm 28.50$ & $114.67 \pm 21.90$ \\
\hline Gain & $24.93 \pm 5.05$ & $25.69 \pm 0.15$ & $27.40 \pm 7.31$ & $17.1 \pm 10.23$ \\
\hline Ving
\end{tabular}

Values are mean \pm SD for six rats.

Control Daily $3.0 \mathrm{ml}$ orally distilled water

Crown Daily $3.0 \mathrm{ml}$ orally fed fermented Crown rice beverage

Narica Daily $3.0 \mathrm{ml}$ orally fed fermented Narica rice beverage

Pabenjeda Daily $3.0 \mathrm{ml}$ orally fed fermented Pabenjeda rice beverage

Table.5 Blood haematology of rats fed fermented rice beverages supplemented with whey and hashab gum

\begin{tabular}{|c|c|c|c|c|c|}
\hline \multirow[t]{2}{*}{ Parameter } & \multicolumn{5}{|c|}{ Rat groups orally fed different fermented rice supplemented with whey and gum } \\
\hline & Standard Range & Crown & Narica & Pabenjeda & Control \\
\hline RBC $\left(10^{6} u / L\right)$ & $7.27-9.65$ & $07.90 \pm 0.71_{\mathrm{a}}$ & $08.05 \pm 0.42_{\mathrm{a}}$ & $07.48 \pm 0.35_{\mathrm{a}}$ & $07.67 \pm 0.17_{\mathrm{a}}$ \\
\hline HGB (g /d/L) & $13.7-17.6$ & $14.13 \pm 0.92$ a & $14.20 \pm 0.73_{\mathrm{a}}$ & $13.22 \pm 10.60 \mathrm{a}$ & $13.85 \pm 0.41_{\mathrm{a}}$ \\
\hline WBC $\left(10^{3} \mathbf{u} / \mathrm{L}\right)$ & $1.96-8.25$ & $06.96 \pm 0.61_{\mathrm{a}}$ & $06.94 \pm 0.59 \mathrm{a}$ & $06.90 \pm 0.23 \mathrm{a}$ & $07.02 \pm 0.27 \mathrm{a}$ \\
\hline HCT (\%) & $39.6-52.5$ & $47.80 \pm 3.28_{\mathrm{a}}$ & $44.30 \pm 242 \mathrm{a}$ & $47.43 \pm 2.3_{\mathrm{a}}$ & $46.03 \pm 1.43 \mathrm{a}$ \\
\hline MCV fL(um²) & $48.9-57.5$ & $54.14 \pm 3.21_{\mathrm{a}}$ & $52.65 \pm 2.15_{\mathrm{a}}$ & $49.8 \pm 2.5_{\mathrm{a}}$ & $54.41 \pm 3.12_{\mathrm{a}}$ \\
\hline $\operatorname{MCHC}(\mathrm{g} / \mathrm{L})$ & $32.9-37.5$ & $29.80 \pm 0.68 \mathrm{a}$ & $29.84 \pm 0.27 \mathrm{a}$ & $29.63 \pm 0.68 \mathrm{a}$ & $30.10 \pm 0.43 \mathrm{a}$ \\
\hline MCH (pg) & $17.1-20.4$ & $17.18 \pm 0.35 \mathrm{a}$ & $17.07 \pm 0.37 \mathrm{a}$ & $17.15 \pm 0.48 \mathrm{a}$ & $17.57 \pm 0.31_{\mathrm{a}}$ \\
\hline HCV & - & $59.48 \pm 1.49 a$ & $58.22 \pm 2.76_{a}$ & $59.97 \pm 1.57 \mathrm{a}$ & $59.68 \pm 1.53_{\mathrm{a}}$ \\
\hline Platelets (PLT) & $638-1177$ & $659.3 \pm 22.01$ & $644 \pm 23.10_{a}$ & $638 \pm 28.7 \mathrm{a}$ & $716.5 \pm 15.1_{\mathrm{a}}$ \\
\hline MPV Fl $\left(\mathbf{u m}^{3}\right)$ & $6.2-9.4$ & $7.58 \pm 0.26_{a}$ & $7.92 \pm 0.13_{\mathrm{ab}}$ & $7.37 \pm 0.49_{b}$ & $7.83 \pm 0.10_{a}$ \\
\hline PDW \% & $43.2-64.3$ & $8.98 \pm 0.50_{a}$ & $9.46 \pm 0.37 \mathrm{a}$ & $8.92 \pm 0.79 a_{a}$ & $9.55 \pm 0.53 \mathrm{a}$ \\
\hline RWD Cv / \% & - & $18.00 \pm 0.93 \mathrm{ab}$ & $16.18 \pm 1.21_{\mathrm{a}}$ & $15.63 \pm 0.79 a$ & $17.75 \pm 1.26_{\mathrm{a}}$ \\
\hline
\end{tabular}

Values are mean \pm SD for 3 rats.

Values that bear different superscript letter in the same raw are significantly different at $p<0.05$.

Control Daily $3.0 \mathrm{ml}$ orally distilled water

Crown Daily $3.0 \mathrm{ml}$ orally fed fermented Crown rice beverage

Narica Daily $3.0 \mathrm{ml}$ orally fed fermented Narica rice beverage

Pabenjeda Daily $3.0 \mathrm{ml}$ orally fed fermented Pabenjeda rice beverage 
Table.6 Blood biochemistry of rats fed fermented rice beverages supplemented with whey and hashab gum

\begin{tabular}{|c|c|c|c|c|c|}
\hline \multirow[t]{2}{*}{ Parameter } & \multicolumn{5}{|c|}{ Rat group } \\
\hline & Standard Range & $\begin{array}{l}\text { Crown rice } \\
\text { fed group }\end{array}$ & $\begin{array}{l}\text { Narica rice } \\
\text { fed group }\end{array}$ & $\begin{array}{l}\text { Pabenjeda rice } \\
\text { fed group }\end{array}$ & $\begin{array}{l}\text { Control } \\
\text { fed group }\end{array}$ \\
\hline T-Protein (g / dL) & $5.2-7.1$ & $6.20 \pm 0.20_{a}$ & $6.14 \pm 0.78_{a}$ & $6.10 \pm 1.04_{\mathrm{a}}$ & $6.08 \pm 0.36_{a}$ \\
\hline Cholesterol (mg/ dL) & $40-130$ & $82.67 \pm 8.80_{\mathrm{ab}}$ & $89.4 \pm 9.69 \mathrm{ab}$ & $78.88 \pm 6.06_{a}$ & $93.50 \pm 5.86_{\mathrm{a}}$ \\
\hline Tri-glyceride (mg/ dL) & - & $77.5 \pm 14.85_{\mathrm{ab}}$ & $74.33 \pm 5.24_{b}$ & $79.67 \pm 11.72_{\mathrm{ab}}$ & $93.00 \pm 5.70_{\mathrm{a}}$ \\
\hline Uric acid (mg / dL) & - & $4.9 \pm 2.09_{\mathrm{a}}$ & $4.38 \pm 0.388_{a}$ & $4.32 \pm 0.35 \mathrm{a}$ & $4.06 \pm 0.02 \mathrm{a}$ \\
\hline Glucose (mg /L) & $70-208$ & $76.50 \pm 11.47_{\mathrm{ab}}$ & $72.06 \pm 12.21_{\mathrm{ab}}$ & $72.83 \pm 9.26_{a}$ & $77.83 \pm 5.88_{\mathrm{ab}}$ \\
\hline Urea (mg/dL) & $12.3-24.6$ & $36.67 \pm 7.45_{\mathrm{a}}$ & $32.00 \pm 9.92 \mathrm{a}$ & $33.33 \pm 9.05_{\mathrm{a}}$ & $29.83 \pm 1.84_{\mathrm{a}}$ \\
\hline Albumin (g /dL) & $3.40-4.8$ & $4.0 \pm 0.20_{\mathrm{a}}$ & $3.98 \pm 0.22_{\mathrm{a}}$ & $4.0 \pm 0.32 \mathrm{a}$ & $4.1 \pm 0.18_{\mathrm{a}}$ \\
\hline $\operatorname{ALP}(\mathbf{U} / \mathbf{L})$ & $62-230$ & $72.33 \pm 8.76_{a}$ & $75.00 \pm 11.47_{\mathrm{a}}$ & $83.00 \pm 11.87 \mathrm{a}$ & $74.50 \pm 10.29 a$ \\
\hline ALT (U/L) & $18-45$ & $20.33 \pm 3.83_{\mathrm{ab}}$ & $25.00 \pm 3.39 \mathrm{a}$ & $19.83 \pm 2.32 \mathrm{a}$ & $20.57 \pm 1.64_{a b}$ \\
\hline $\operatorname{AST}(\mathrm{U} / \mathrm{L})$ & $74-143$ & $96.17 \pm 11.69 a_{a}$ & $67.80 \pm 8.64_{\mathrm{a}}$ & $63.33 \pm 9.77 \mathrm{a}$ & $67.33 \pm 11.11_{\mathrm{a}}$ \\
\hline
\end{tabular}

Values are mean \pm SD 3 rats

Values that bear different superscript letter in the same raw of each specific parameter are significantly different at $\mathrm{p}<0.05$.

Control Daily $3.0 \mathrm{ml}$ orally distilled water

Crown Daily $3.0 \mathrm{ml}$ orally fed fermented Crown rice beverage

Narica Daily $3.0 \mathrm{ml}$ orally fed fermented Narica rice beverage

Pabenjeda Daily $3.0 \mathrm{ml}$ orally fed fermented Pabenjeda rice beverage

\section{Blood biochemistry of rats fed fermented rice beverages supplemented with whey and hashab gum}

There was no significant $(\mathrm{P}<0.05)$ differences in blood serum biochemistry results between different groups of rats including the control; except in cholesterol, tri-glyceride, glucose and ALT (Table 6). As presented in Table 6, Crown rice fed group of rat contained the highest level of T- Protein and Urea. Narica rice fed group was the richest in ALP and ALT. While the control group of rats was the highest in results of cholesterol, tri-glyceride, glucose and albumin. Despite of the variation in level of blood biochemistry parameters between different rat groups, their levels were within the standard range of rat (Table 6). Nevertheless, urea level in all groups of rats fed the fermented rice and the control was outside the standard range reported in Table 6.

Fortunately feeding fermented rice beverage with Bifidobacterium strains did not adversely affect fed rats behavior. All survived rat involved in this study showed normal behavior characteristics. These findings are in agreement with Kabier et al., (2005) statement on normal behavioral characteristics and general heath of mice fed Bifedobacterium strains supplemented to fermented rice beverage.

There were variations in feed intake and water consumption between different rat groups orally fed fermented rice beverages. El-Kheir et al., (2009) stated that birds fed high level of gum arabic increased feed intake due to enhanced palatability of the diet. Whereas Calame et al., (2011) stated that gum arabic supplemented feed led to decreased caloric intake, increased feeling satiated and enhanced the absorption of minerals depending on the body need and health. Therefore, the difference in the feed consumption between different groups of rats in this finding and other studies might be due to variances in type of experimental animal and composition of supplemented feed. 
Commonly in animal model studies, losses of weights are signs of negative health effects. The losses could take place in case of illnesses or toxicity (Abdo et al., 2001). Potential interpretation of better weight of rat groups fed fermented rice beverages as compared to the control might be due to higher level of carbohydrate (rice beverge), protein (whry) and less hashab gum (used during fermentation). In addition, Bifidobacteriun longom BB 536 played role in improved physiological conditions of the gut via better metabolic activity and absorption of nutrients. However, in study with pure gum Arabic by Chandalia et al., (2000), Howarth et al., (2001) and Lattimer and Haub (2010) found that supplementation of feed with dietary fiber (gum arabic) resulted in less body weight gain, due to the fact that high intake of dietary fiber, such as gum arabic could exert beneficial effects on fat metabolism (Ali et al., 2009; Slavin, 2003). Also dietary fiber was reported to promote satiety and satiation, improve glycemic control, affects gastric emptying and stomach hormone secretion, and therefore reduces weight gain (Chandalia et al., 2000). In human, gum arabic treatment certainly modified the body weight decrease body mass index and body fat percentage among healthy adult female, thus it could be used in the treatment of obesity (Babker et al, 2012). Gum arabic can help in management of body weight (Mahmoud, 2018). Therefore, body weight gain in rat investigation might mainly depend on the nutritional composition profile of the supplement used.

Blood haematology commonly used to evaluate the toxicity status of animal. In fact there were no any indication of any toxicity or serious illness symptoms on rats group fed the fermented rice beverage. In addition no signs of any deviation or deficiencies in CBC parameters were recorded. Further there are considerable signs of positive health effect on
Red blood cells (RBC), haemoglobin (HGB) when compared with the control. As presented in Table 5, Crown rice fed group of rat contained the highest level of HCT and RWD. Narica rice fed group was the richest in RBC, HGB and MPV. While the highest level of HCV was in rat group fed Pabenjeda fermented rice. Generally, the control group of rats was the highest in results of WBC, MCV, MCHC, MCH, Platelets and PDW. Despite of the variation in level of all haematological parameters between different rat groups, their levels were within the standard range of rat (Table 5). This supported by absence of any signs of diseases and toxicity associated with adaptability to environmental conditions as stated by Koubkova et al., (2002).

All levels of blood biochemistry parameters reported in this study were within the standard range of rat. Urea in all groups of rats fed the fermented rice and the control (29.83 - 36.67 $\mathrm{mg} / \mathrm{Dl})$ was outside the standard range (12.3 $24.6 \mathrm{mg} / \mathrm{dL}$ ). However, between different rat groups there were no significant difference in urea. Lower levels of cholesterol, glucose and triglyceride in all rats groups fed the fermented rice than the control might be due to presence of probiotic strain BB 536. Shah (2007) stated that beneficiary effects of probiotic strains were lowering cholesterol level in blood, improving lactose metabolism, lowering blood pressure, anticancerogenic properties and immune system stimulation. Mahmoud (2018) stated that the original component of the metabolic profile were glucose, urea, albumins and others, The plasma proteins, including albumin are in a state of equilibrium with amino acids and tissue proteins. Albumin is synthesized by the liver and functions to maintain the osmotic pressure within the circulating system. Hankins (2006), Lager and Jordan (2012) reported that the decrease in albumin level is due to characteristic of liver, kidney diseases, 
inflammatory status and malnutrition. The blood urea level is used for measuring the adequacy of dietary protein level as well as nitrogen utilization efficiency. Urea nitrogen concentrations are influenced by a wide range of factors, including dietary protein intake and intestinal degradability, dietary amino acid composition, protein intake relative to requirements, liver and kidney functions, muscle tissue breakdown and dietary carbohydrate amount (Van Sauna, 2004). Bobe and Behrensmeyer (2004) concluded that serum levels, of glucose, protein and urea are indications of liver function. In general, blood metabolise were affected by diet composition and /or presentation, indicating that some metabolites could reflect the nutritional and / or physiological status of rats. Results of ALP, AST levels in blood serum of fed rats indicated no significant $(\mathrm{p}<$ 0.05) difference between groups except in ALT. However, theses enzymes marker values were within the standard range of rat (Table 6). These result indicated that dietary fiber in general affected the body metabolism and hepatic activities which induced body weight gain, feed intake and water consumption, mineral absorption and general health. All these parameters represent liver function. While the increase in the liver enzymes levels outside the standard range indicates liver damage. However the decreases in the activities of these liver enzymes were not considered to give any toxicological significance as stated by Mahmoud (2018). Blood biochemistry results in this study did not show any abnormalities in serum blood parameters. In addition Liver and kidney function tests and serum protein profile are important parameters in determining the safety of functional ingredient of final product (Farage et al., 2006; Patel et al., 2008).

In conclusion the general health of rat fed the different fermented rice was normal based on weight gain and behaviour characteristic Moreover, absence of abnormalities in blood biochemistry results including liver and kidney function, serum protein profile indicated safety of different fermented rice beverages supplemented with whey and hashab gum on fed rats. Thus the fermented rice beverages are safe for human consumption. In addition, fermented rice beverages exerted beneficial effects on lowering cholesterol, glucose and triglyceride in blood serum of fed rats.

\section{References}

Abdo, K.M., Cunningham, M.L., Snell, M.L., Herbert, R.A, Travlos, G.S, EldArige, S.R. and Bucher, J.R. (2001). 14 Week toxicity and cell proliferation of methyl eugenol administered by gavage to F344 rats and B6C3F1 mice. Food and Chemical Toxicology 39: 303 - 316.

Abdul -Hadi, A.H., Mahmoud. A.E and AbdelWahab, H.M. (2010). Effect of gum Arabic on coagulation system of albino rats. Int.J.Pharm.Tech.Res. 2:1762-1766.

Ali, B.H., Ziada, A., and Blunden, G. (2009). Biological effects of gum Arabic: a review of some recent researches. Food Chem. Toxicol. 47(1):1-8.

Babiker, R., Merghani, T.H., Elmusharaf, K. (2012). Effects of gum Arabic ingestion on body mass index and body fat percentage in healthy adult females: two-arm randomized, placebo controlled, double-blind trial. Nutr J., 11: 1475-2891.

Blandino A., Al-Aseeri, M.E., Pandiella, S.S., Cantero, D., Webb, C. (2003). Cerealbased fermented foods and beverages. Food Research International 36(6): 527 543.

Bobe ,R. and Behrensmeyer , A.K. (2004). The expansion of grassland ecosystems in Africa in relation to mammalian evolution and the origin of the genus Homo, 
Palaeoclimatology. Palaeoecology 207:399 - 420.

Calame, W., Weseler, A.R., Viebke, C., Flynn, C. and Siemensma A.D. (2008). Gum Arabic establishes prebiotic functionality in healthy human volunteers in dose dependent manner. The British journal nutrition 100(6): 1269-75.

Chandalia, M., Garg, A., Lutjohann, D., Von Bergmann, K., Grundy ,S.M. and Brinkley, L.J. (2000). Beneficial effects of high dietary fiber intake in patients with type 2 diabetes mellitus. $\mathrm{N}$ Engl J Med. 342:1392-1398.

Collins, M.D. and Gibson, G.R. (1999). Probiotics, prebiotics, and synbiotics: approaches for modulation the microbial ecology of the gut. The American Journal of Clinical Nutrition 69 (5): $1052 \mathrm{~s}-1057 \mathrm{~s}$.

De Vaux, A., Morrison, M., Hutkins, R.W. (2002). Displacement of Escherichia coli O157:H7 from rumen medium containing prebiotic sugars. Applied Environmental Microbiology 68: 519524.

Desai, A.R., Powell, I.B. and shah, N.P. (2004). Survival and activity of probiotc in skim milk containing prebiotics. Journal of Food Science 69: 57-60.

El-Kheir, M.K.S., Ishag, K.E.A., Yagoub, A. A. and Abubaker, A.A. (2009). Supplementation laying hen diet with gum Arabic (Acacia Senegal): Effect on egg production, shell thickness and yolk content of cholesterol, calcium and phosphorus. Asian j. poultry sci. 3: 9-14.

Farage, R.S., Mahmoud, E.A., Basuny, A.M. and Ali, R.F.M. (2006). Influence of crude olive leaf juice on rat liver and kidney functions. International Journal of Food Technology 41: 790-798.

Gibson, G.R., Robertfroid, M.B. (1995). Dietary modulation of human colonic microbiota; Introducing the concept of Prebiotic. Journal of Nutrition 125 (6): $1401-12$.

Hankin, J. H. Howarth, N.C., Murphy, S.P.,
Wilkens, L.R. and Kolonel, L.N (2006). Dietary energy density is associated with overweight status among 5 ethnic groups in the Multiethnic Cohort Study. The Journal of Nutrition 136 (8): 22432248.

Holzapfel, W.H., Geisen, R., Schillinger, U. (1995). Biological preservation of foods with reference to protective cultures, bacteriocins and food-grade enzymes. International Journal of Food Microbiology 24: 343 - 362.

Howarth, N.C., Saltzman, E., Roberts, SB. (2001). Diatary fiber and weight regulation. Nur Review 59(5):129-139.

Kabeir ,B.M., Abd Aziz, S., Muhamed, M. and Yazid, A.M. (2005). Growth of Bifidobacterium longum BB536 in media (fermented cereal porridge) and their survival during storage. Let. AppI. Microbial 141:12-131.

Kojima, T., Yaeshima, T., Ishibashi, N., Shimamura, S., Hayasawa, H. (1996). Inhibitory effects of human-derived bifidobacterium on pathogenic Escherichia coli serotype O-111. Bioscience Microflora 15: 17 - 22.

Koubkova, M., Knizkova, I., Kunc, P., Hartlova, H., Flusser, J. and Dolezal, O. (2002). Influence of high environmental temperatures and evaporative cooling on some physiological, haematological and biochemical parameters in high yielding dairy cows. Czech J. Anim. Sci. 47:30-318.

Lager, K. and Jordan, E. (2012). The metabolic profile for modern transition dairy cow. The Mid- South Ruminant Nutrition conference, Texas, pp 9-16.

Lattimer, J.M. and Haub, M.D. (2010). Effects of dietary fiber and its components on metabolic health nutrients 2 (12): 12661289.

Mahmoud, H.M. (2018). Assessment of Two Types of Gum Arabic as Probiotic. Ph.D. Thesis, Sudan university of science and technology.

Marshall, K.R., Harper. W.J. (1988). Whey protein concentrates. International Dairy 
Federation 388/B: 21-32.

Naidu, A.S., Bidlac, W.R. and Clemens, R.A. (1999). Probiotic spectra of lactic acid bacteria. Critical Reviews in Food Science and Nutrition 39: 13 - 126.

Namba, K., Yaeshima, T., Ishibashi, N., Hayasawa, H., Yamazaki, S. (2003). Inhibitory of Bifidobacterium longum on inter hemorrhagic Escherichia coli O157: H7. Bioscience Microflora 22: 85 $-91$.

Patel, C., Dadhaniya, P., Hingorani, L. and Soni, M.G. (2008). Safety assessment of pomegranate fruit extract: acute and sub chronic toxicity studies, Food Chemistry and Toxicology 46: 2728-2735.

Prado, F.C., Parada, J.L., Pandey, A., Soccol, C.R. (2008). Trends in non-dairy probiotic beverages. Food Research International 41: 111-123.

Saxelin, M., Pessi, T. and Salminen, S. (1995). Fecal recovery following oraladministration of Lactobacillus strain GG (ATCC-53103) in gelatin capsules to healthy volunteers. International Journal of Food Microbiology, 25: 199203.

Schrezenmeir, J. and De Vrese, M. (2001). Probiotics, prebiotics, and synbiotics approaching a definition. American Journal of Clinical Nutrition, 73: 361S$364 \mathrm{~S}$.

Shah, N. (2007). Functional cultures and health benefits. International Diary Journal 17:1262-1277.
Shreyanshm, J., Revant, G., and Shreya, J. (2013). Development of Low Cost Nutritional Beverage from Whey. Journal of Environmental Science, Toxicology and Food Technology Volume 5: 73 - 88.

Siro, I.N., Kápolna, E., Kápolna, B.T., Lugasi, A. (2008). Functional food. Product development, marketing and consumer acceptance-A review. Appetite 51(3): $456-467$.

Slavin, J. (2003). Why whole grains protective: biological mechanisms. Proc. Nutr. Soc. 62 (1): 129-134.

Tamime, M.A.H.M., Palframan, R.J.,Cooper, J.M., Gibson, G.R. and Rastall, R.A. (2006). In vitro fermentation of sugar beet arabinan and arabinooligosaccharides by the human gut microflora. J Appl. A.(Ed.), Oxford, UK, pp39-56.

Van Sauna, R.J. (2004). Using a pooled sample technique herd metabolic profile screening in Proc. 12th International conference production diseases of farm animals, east lansing, Michigan, July 1823, Pp. 91.

Ventura, M., Canchaya, C., Tauch, A., Chandra, G., fitzgeralda, G.F., Cater, K.F. and Van Sideren, D. (2007). Genomics of Actinobacteria: Tracing the evolutionary history of an ancient phylum, Microbial. Mol Biol Rev. 71: 495 -548.

\section{How to cite this article:}

Barka Mohammed Kabeir and Maha Abdalla Mohamed Ibrahim. 2021. Safety of Bifidobacterium longum BB.536 Fermented Sudanese Rice Types Denoted Locally as Crown, Narica and Pabenjeda Beverages Assessed on Albino Rats. Int.J.Curr.Microbiol.App.Sci. 10(01): 352-362. doi: https://doi.org/10.20546/ijcmas.2021.1001.044 